\title{
Agronomic characterization of eighteen cucurbitaceae cultivars used for food in Niger.
}

\author{
Haoua SABO ${ }^{1}$, Hassimi SADOU ${ }^{1}$, Ibrahim Adamou AMOUKOU ${ }^{3}$, Mousbahou MALAM ALMA ${ }^{1}$, \\ Mahamane Saadou². \\ ${ }^{1}$ Department of Chemistry, Abdou Moumouni University. BP: 10662. Niamey. Niger. \\ 2 Department of Biology, Faculty of Sciences, Abdou Moumouni University. BP: 10662. Niamey. Niger. \\ ${ }^{3}$ Faculty of Agronomy, Abdou Moumouni University. BP: 10662. Niamey. Niger. \\ *Corresponding Author: hseinisabo@yahoo.frTel: 00 (227) 96288492 Fax: 00 (227) 20315072.
}

Original submitted in on $7^{\text {nd }}$ July 2014. Published online at www.m.elewa.org on 30th September 2014. http://dx.doi.org/10.4314/jab.v81i1.3

\begin{abstract}
:
Objective: Agronomic potentialities of 18 cucurbitaceous cultivars from two species were assessed in a period of two years on the experimental field of the University Of Niamey Faculty Of Sciences. The experiment was a complete random block. Seventeen (17) cultivars of the Lagenaria siceraria species of which only one species from the Citrullus colocynthis.

Methodology and results: Thirteen (13) characteristics were studied. Variance analyses showed that there was very significant difference $(p=0.05)$ between cultivars for all studied characteristics, except the duration of the emergence, the date of fructification, the width of the fruit and the weight of the seed the first year. In this way, short-cycle and long cycle cultivars, as well as productive and less productive cultivars are identified. Correlations between the different characteristics showed that the yield in berries is very positively correlated to the weight of a berry $(r=0.76)$ and the number of seeds per berry $(r=0.61)$ and negatively with the width $(r=-$ $0.66)$ and the length $(r=-0.73)$ of a seed. The average production in berries is 17 per plant in the first year against 6 the second year. Better productivity is achieved with Citrullus colocynthis, which gave 82 berries per plant the $1^{\text {st }}$ year. The average yield in seeds was $180.15 \mathrm{~kg} / \mathrm{ha}$ in the first year and $704.30 \mathrm{~kg} / \mathrm{ha}$, in the second year.

Conclusion and application of results: Niger cucurbitaceous are unknown and the results of this study show that they have a lot of potentiality and can contribute to achieve the Millennium Development Goals, especially in its food security and fight against poverty programs, since they represent an important source of income for the population.
\end{abstract}

Key words: cucurbitaceous, Citrullus colocynthis, Lagenaria siceraria, agronomic characteristics, Niger.

\section{INTRODUCTION}

In developing countries, the exploitation of local plant resources is certainly a way to achieve food security, especially in countries with a high demographic growth. However, it requires the preservation and availability of a high level of genetic diversity of these resources (Barilla, 2012). Many local plant resources valorisation research programs have been developed to support the government of Niger in its poverty alleviation programs and food its security effort, through qualitative and quantitative improvement of alternative foods, scientifically less known, but widely used by Nigeriens. All parts of the plant (leaves, flowers, seeds and mature and immature berries) can be used for food depending 

food in Niger

on the species. Starch can be extracted from roots (Ismail et al., 2010; Mohammed, 2011). Some cultivars of Lagenaria siceraria are cultivated in a strictly utilitarian purpose to obtain utilities such as (calabashes, spoons, water containers). Growing cucurbitaceous ("Tanda" local name in Zarma) represents a potential source of additional income as well as a source of immediate food needs of the family unit. In most rural African communities, Lagenaria siceraria primitive roots are generally distinguished by the size and shape of the berry, and are designated by a common name related to these morphological differences (Beshir and Babiker, 2009; Nyam et al., 2009). In Ivory Coast, farmers refer to seed size when talking about plants with edible seeds. In addition, in the Cucurbitaceous family, the important contribution of the characteristics of berries and seeds to the morphological variability has been reported for some species (Abiodun and Adeleke, 2010; Gundele et al., 2013). Research on agronomic and botanical characteristics of cucurbitaceous in West Africa is very recent. (Leonie et al., 2009). In Niger, despite the nutritional, socio-economic and cultural importance of cucurbitaceous, very few studies have been conducted for the characterization, the development and promotion of this biological material. If many studies have

\section{MATERIALS AND METHODS}

Experimental site: The tests were carried out at the Faculty of Sciences and Technology at Abdou Moumouni University of Niamey experimental site located $\left(13^{\circ} 30^{\prime} \mathrm{N}\right.$; $2^{\circ} 08^{\prime} \mathrm{E} ; 216$ a.s.l). The soil is made of alluvial sediment deposits (mud, sands, gravels, stones). The climate is characterized by a rainy season (from June to October), a cold season (from November to February) and a hot season (from March to May). It rains $522.3 \mathrm{~mm}$ per year in average [NIS, 2013].

Plant Material: Botanists of the Faculty of Sciences and Technology identified different varieties to which they gave names according to their fruits shape or aspect (figure 1), then, they used codes and a number to refer to species (table 1). This led to 18 cultivars including 17 (LS1 to LS17) of the Lagenaria siceraria species and a cultivar of the Citrullus colocynthis species (Table 1). There are climbing and creeping cultivars. The berry can be big or small, of varied shapes (calabash, gourd and ladle) smooth or rough aspect (Figure 1). examined the biochemical compositions of seeds (Abiodun and Adeleke, 2010; Gundele et al., 2013), very few studies, on the contrary have addressed production aspects. In addition, it was important to assess the agronomic characteristics of these species in Niger considering varietal aspects. Two species namely Citrullus colocynthis (linn.) Schrad and Lagenaria siceraria (Molin.) Standl, were chosen as their products and by-products are commonly used for food in Niger. The seeds are used for the production of dough, cakes and edible oils in the Zinder region. The seeds of Citrullus Colocynthis represent an important source of income for the population and depending on the season, the price of a $100 \mathrm{~kg}$ sack varies between 77 and $154 €(100$ and 200 USD). Thus, the study was carried out on the one hand for the determination of characteristics related to the germination, the emergence, the flowering, the fructification, berries, seeds parameters and yields on the other, the setting of performance criteria for different cultivars. The work on cucurbitaceous is significant because of their seeds. The work on cucurbitaceous was chosen because their seeds, considered by some analysts as "saviours of arid regions with multiple purpose." (Schafferman et al., 1998).

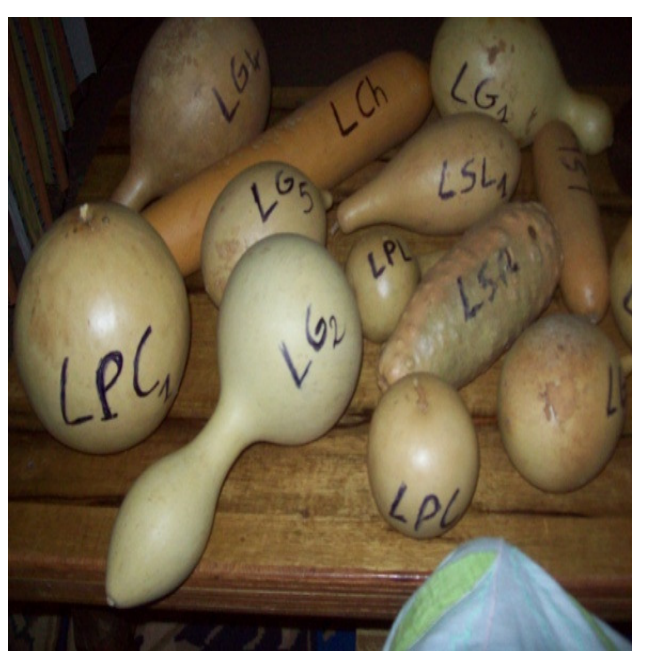

Figure 1: Form of berries of the studied cultivars

The seeds were acquired from Niamey markets and other localities of Niger (Zinder, Doutchi, Keita and Goubèye) 

food in Niger

(Table 1). The vernacular names are reported in (Hausa

(Peyre, 1979). and Zarma) the two most spoken languages in Niger

Table1: Composition of plant material according to the type of growth, shape and / or aspect of the berry, vernacular names and provenance.

\begin{tabular}{|l|l|l|l|l|l|}
\hline Varieties & Type of Growth & $\begin{array}{l}\text { Berry shape and / or } \\
\text { aspect }\end{array}$ & Djerma & Haussa & Berries provenance \\
\hline LS 1 & Climbing & guitar & Souta'n & Chantu & Katako market, Niamey \\
\hline LS 2 & Climbing & rough & $\begin{array}{l}\text { Kassa } \\
\text { kassa }\end{array}$ & Sana'a & Niamey big market \\
\hline LS 4 & Climbing & Smooth & $\begin{array}{l}\text { Kassa } \\
\text { kassa }\end{array}$ & Sana'a & Katako market, Niamey \\
\hline LS 5 & Climbing & Big calabash & Gassu & Koriya & Zinder \\
\hline LS 6 & Climbing & Small gourd & Gombo & Liddeye & Niamey big market \\
\hline LS 7 & Climbing & big gourd & Zoloo & Djandama & Daanako market, Niamey \\
\hline LS 8 & Climbing & Small calebash & Gassu & Koriya & Niamey big market \\
\hline LS 9 & Creeping & ladle with small tip & Gombo & Liddeye & Doutchi \\
\hline LS 10 & Climbing & Ladle wth big tip & Gombo & Liddeye & Doutchi \\
\hline LS 11 & Climbing & rough & $\begin{array}{l}\text { Kassa } \\
\text { kassa }\end{array}$ & Sana'a & Doutchi \\
\hline LS 12 & Climbing & smooth & $\begin{array}{l}\text { Kassa } \\
\text { kassa }\end{array}$ & Sana'a & Doutchi \\
\hline LS 13 & Climbing & big gourd & Zoloo & Djandama & Keita \\
\hline LS 14 & Climbing & Cucumber like & - & Zoungourou & Niamey \\
\hline LS15 & Climbing & rough & $\begin{array}{l}\text { Kassa } \\
\text { kassa }\end{array}$ & Sana'a & Goubèye (Doutchi) \\
\hline LS 16 & Climbing & rough & $\begin{array}{l}\text { Kassa } \\
\text { kassa }\end{array}$ & Sana'a & FAST site \\
\hline LS 17 & Climbing & rough & $\begin{array}{l}\text { kassa } \\
\text { kassa }\end{array}$ & Sana'a & Goubèye (Doutchi) \\
\hline CC & Creeping & Smooth & Kafurdu/Guna & FAST site \\
\hline
\end{tabular}

$\mathrm{LS}=\mathrm{L}$. siceraria $\mathrm{CC}=\mathrm{C}$. Colocynthis

\section{Methods}

Experimental design in the field : The ground was weeded, drilled and the distance between the planting holes determined. The experiment for both years (2009 and 2010) took place on the $21^{\text {st }}$ July, during the rainy season; two types of cultivars, (climbing and creeping) were tested in two different trials without using any fertilizer.

For climbing cultivars: During the two years of experiment, the climbing cultivars (4 in the first year and 14 in the second year) were followed in a complete random block device in three replication plots. In each, replicate plot three plants per sample. The distance between the planting holes was $4 \mathrm{~m}$ and the one between the blocks 1 . Supports were immediately placed at the bottom of plants at the appearance of the first tendrils. According to (Achigan, 2002) tutors help support the weight of berries.

For the creeping cultivars: The same type of device was used for creeping cultivars ( 2 in 1 st year and 4 in 2 nd year) with a distance of $6 \mathrm{~m}$ between the planting holes and 1 between the replication plots. Observations and measurements on the duration of the emergence in Days After Sowing (DAS) were made, the rate of emergence, the date of flowering and fructification, the duration of the cycle, the yield in berries and in seeds, the widths and lengths of berries and seeds. The correlation between the shape of berries and the number of seeds could help 

food in Niger

researchers to know beforehand the number of seeds in relation to the height of berries.

Statistical analysis: An analysis of variance was performed for all characters observed by using Statitix software. In case of significant difference between

\section{RESULTS AND DISCUSSION}

Results of variance analysis: The variance analysis in table 2 shows that there is a significant difference between cultivars for all measured parameters over the two years except for the level of the emergence duration, cultivars, comparison of averages' tests (Tukey HSD test) was conducted for the concerned characteristics to determine the groups of homogeneous cultivars. Then a correlation analysis was made among the various characteristics.

of the date of fructification, the width of the berries and the weight of a first year seed. The following results on the comparison of averages will enlighten us on the different cultivar groups for all these characters.

Table 2: Variance analysis for measured parameters.

\begin{tabular}{|c|c|c|c|c|c|c|}
\hline Character & Test & DF & SS & MS & $F$ & $\mathbf{P}$ \\
\hline \multirow[t]{2}{*}{$\mathrm{DL}$ in DAS } & Year 1 & 5 & 12.44 & 2.48 & $2.22 \mathrm{~ns}$ & 0.1329 \\
\hline & Year 2 & 17 & 84.00 & 4.94 & $4.04^{\star *}$ & 0.0003 \\
\hline \multirow[t]{2}{*}{$\mathrm{RL}(\%)$} & Year 1 & 5 & 5357.61 & 1071.52 & $3.65^{*}$ & 0.0387 \\
\hline & Year 2 & 17 & 10416.70 & 612.74 & $2.78^{* *}$ & 0.0055 \\
\hline \multirow[t]{2}{*}{ FLO } & Year 1 & 5 & 316.94 & 63.38 & $63.38^{* *}$ & 0.0003 \\
\hline & Year 2 & 17 & 1253.65 & 73.74 & $12.86^{* *}$ & 0.0000 \\
\hline \multirow[t]{2}{*}{ FRU } & Year 1 & 5 & 65.61 & 13.12 & $0.62 \mathrm{~ns}$ & 0.6888 \\
\hline & Year 2 & 17 & 1342.67 & 78.98 & $11.82^{* *}$ & 0.0000 \\
\hline \multirow[t]{2}{*}{ NBP } & Year 1 & 5 & 15421.20 & 3084.23 & $7.91^{* *}$ & 0.0030 \\
\hline & Year 2 & 17 & 728.59 & 42.85 & $1.95^{*}$ & 0.0484 \\
\hline \multirow[t]{2}{*}{ WtB } & Year 1 & 5 & 334401 & 66880.20 & $40.54^{* *}$ & 0.0000 \\
\hline & Year 2 & 17 & 1746793 & 102753 & $11.31^{* *}$ & 0.0000 \\
\hline \multirow[t]{2}{*}{ WB } & Year 1 & 5 & 21.54 & 4.30 & $1.37 \mathrm{~ns}$ & 0.3141 \\
\hline & Year 2 & 17 & 1928.60 & 113.44 & $9.48^{* *}$ & 0.0000 \\
\hline \multirow[t]{2}{*}{ LB } & Year 1 & 5 & 2794.89 & 558.97 & $95.31^{* *}$ & 0.0000 \\
\hline & Year 2 & 17 & 1653.62 & 97.27 & $3.89^{* *}$ & 0.0004 \\
\hline \multirow[t]{2}{*}{ NSB } & Year 1 & 5 & 324082 & 64816.50 & $16.94^{* *}$ & 0.0001 \\
\hline & Year 2 & 17 & 1381245 & 81249.70 & $37.39^{* *}$ & 0.0000 \\
\hline \multirow[t]{2}{*}{ WSB } & Year 1 & 5 & 2609.95 & 521.99 & $6.98^{* *}$ & 0.0047 \\
\hline & Year 2 & 17 & 12740.70 & 749.45 & $6.85^{\star *}$ & 0.0000 \\
\hline \multirow[t]{2}{*}{ LS } & Year 1 & 5 & 1.15 & 0.23 & $16.28^{* *}$ & 0.0002 \\
\hline & Year 2 & 17 & 24.79 & 1.45 & $3.13^{* *}$ & 0.0023 \\
\hline \multirow[t]{2}{*}{ WS } & Year 1 & 5 & 0.20 & 0.04 & $22.73^{* *}$ & 0.0000 \\
\hline & Year 2 & 17 & 38.57 & 2.26 & $3.01^{\star *}$ & 0.0031 \\
\hline \multirow[t]{2}{*}{ WtS } & Year 1 & 5 & 26.96 & 5.39 & $0.84 \mathrm{~ns}$ & 0.5480 \\
\hline & Year 2 & 17 & 21.74 & 1.27 & $2.85^{\star *}$ & 0.0046 \\
\hline
\end{tabular}

DF = Degree of freedom, $S S=$ Sum Score, $M S=$ Mean score, $F=$ Fisher, $P=$ probability, ${ }^{*}$ significant at the $5 \%$ level ${ }^{* *}$ Significant at $1 \%$ ns = not significant. DE: duration of emergence; ER: emergence rate; FLO: flowering, Fru: fructification; NBP: number of berries per plant ; WtB: weight of berry, WB: width of berry, LB: length of a berry; NSB: number of seeds per berry; WSB: weight of seeds per berry, LS: length of a seed, WS: width of a seed, WtS: weight of a seed.

Table 3 shows that, all of the cultivars had the same emergence duration (7 DAS) the $1^{\text {st }}$ year. However, in the $2^{\text {nd }}$ year two groups of cultivars can be distinguished: The LS5 cultivar represents the latest with 10 days duration in soil. Otherwise, all of the other cultivars of Lagenaria siceraria had a fast emergence of 5 to 6 DAS and 4 DAS for Citrullus colocynthis. As for the first year emergence rate, it varies from 27 to $84 \%$ with an average of $47 \%$. Thus forming three groups of cultivars (Table 3 ). The best group is Citrullus Colocynthis cultivar with $84 \%$ of 

food in Niger

germinating rate. The weakest group is LS1 with $28 \%$. The intermediary group has a germinating rate, which varies from $41-45 \%$. In this group, we have LS2, LS3 of the same form. They constitute with LS5 the climbing cultivars with a germinating rate of $41.66 \%$. In the 2 nd year, we also find three homogeneous groups of emergence rate different from those of year 1 . The best outstanding cultivars have all germinated at $100 \%$. These were LS1, LS3, LS4, LS5, CC, LS7, LS8, LS11 and LS15. The LS2 cultivar is the less outstanding with $50 \%$ emergence rate. Intermediate cultivars germinated between 66 and $84 \%$.

\section{Averages comparison for emergence duration and rate}

Table 3: Averages comparison of different cultivars for emergence duration and rate.

\begin{tabular}{|c|c|c|c|c|}
\hline Cultivars & \multicolumn{2}{|c|}{ Duration of emergence (DL) in DAS } & \multicolumn{2}{|c|}{ Rate of emergence $(R L)$ in \% } \\
\hline Year & 1stYear & $2^{\text {nd }}$ Year & $1^{\text {st }}$ Year & $2^{\text {nd }}$ Year \\
\hline LS1 & $7.00 \pm 1.00 a$ & $6.00 \pm 2.00 \mathrm{~b}$ & $27.66 \pm 4.62 b$ & $100.00 \pm 0.00 \mathrm{a}$ \\
\hline LS2 & $7.00 \pm 1.00 \mathrm{a}$ & $6.00 \pm 2.00 b$ & $41.66 \pm 14.43 a b$ & $50.00 \pm 0.00 b$ \\
\hline LS3 & $7.00 \pm 0.00 a$ & $6.00 \pm 2.00 \mathrm{~b}$ & $41.66 \pm 14.43 \mathrm{ab}$ & $100.00 \pm 0.00 a$ \\
\hline LS4 & $5.00 \pm 1.00 a$ & $5.00 \pm 0.00 b$ & $44.33 \pm 9.81 \mathrm{ab}$ & $100.00 \pm 0.00 a$ \\
\hline LS5 & $7.00 \pm 2.00 a$ & $10.00 \pm 1.00 \mathrm{a}$ & $41.66 \pm 14.43 \mathrm{ab}$ & $100.00 \pm 0.00 a$ \\
\hline CC & $7.66 \pm 1.15 a$ & $4.00 \pm 1.00 \mathrm{~b}$ & $83.33 \pm 28.87 a$ & $100.00 \pm 0.00 a$ \\
\hline LS6 & & $5.00 \pm 1.00 b$ & & $83.33 \pm 28.87 \mathrm{ab}$ \\
\hline LS7 & & $6.00 \pm 2.00 b$ & & $100.00 \pm 0.00 a$ \\
\hline LS8 & & $4.00 \pm 0.00 b$ & & $100.00 \pm 0.00 a$ \\
\hline LS9 & & $5.00 \pm 1.00 b$ & & $66.67 \pm 28.87 a b$ \\
\hline LS10 & & $6.00 \pm 2.00 b$ & & $83.33 \pm 28.87 a b$ \\
\hline LS11 & & $5.00 \pm 1.00 b$ & & $100.00 \pm 0.00 a$ \\
\hline LS12 & & $6.00 \pm 2.00 b$ & & $100.00 \pm 0.00 a$ \\
\hline LS13 & & $6.00 \pm 1.00 b$ & & $100.00 \pm 0.00 a$ \\
\hline LS14 & & $6.00 \pm 2.00 b$ & & $100.00 \pm 0.00 a$ \\
\hline LS15 & & $6.00 \pm 2.00 b$ & & $100.00 \pm 0.00 a$ \\
\hline LS16 & & $5.00 \pm 1.00 b$ & & $83.33 \pm 28.87 a b$ \\
\hline LS17 & & $5.00 \pm 1.00 \mathrm{~b}$ & & $83.33 \pm 28.87 a b$ \\
\hline $\begin{array}{l}\text { Average } \\
\pm \text { SD }\end{array}$ & $6.77 \pm 1.30$ & $5.66 \pm 1.76$ & $46.72 \pm 22.37$ & $91.66 \pm 18.80$ \\
\hline
\end{tabular}

LS = L. siceraria (Molin.) Standl CC = C. Colocynthis (Linn.) Schrad,$S D=$ Standard deviation; There is no significant difference between the means that have the same letters in each column.

Averages comparison for the date of flowering, fructification and the yield in berries at harvest:: Table 4 shows that there are no significant differences between cultivars for flowering and fructification in the $1^{\text {st }}$ year. They flowered and bore fruits respectively 83 and 101 DAS. In 2nd year, cultivars flowered between 32 and 49. Concerning the number of berries per plant, the averages comparison highlighted two homogeneous groups in the $1^{\text {st }}$ year, a low production in berries were observed in Lagenaria siceraria cultivars (3-10 berries), an important production for Citrullus colocynthis (83 berries in average). In the 2nd year, the same trend was observed but with three groups for all cultivars. Citrullus colocynthis has always been the most productive with 16 berries per plant, then between 2 and 9 berries for the median and one berry for the less productive 
Table 4: Averages comparison of different cultivars for the date of flowering, fructification and the number of berries.

\begin{tabular}{|c|c|c|c|c|c|c|}
\hline Variety & \multicolumn{2}{|c|}{ Date of flowering } & \multicolumn{2}{|c|}{ Date of fructification } & \multicolumn{2}{|c|}{ Number of berries/plant* } \\
\hline Year & 1st Year & $2^{\text {nd }}$ Year & $1^{\text {st }}$ Year & $2^{\text {nd }}$ Year & 1st Year & $2^{\text {nd }}$ Year \\
\hline LS1 & $74.00 \pm 2.00 a$ & $49.00 \pm 6.00 \mathrm{a}$ & $96.67 \pm 8.02 \mathrm{a}$ & $59.33 \pm 8.02 a$ & $2.33 \pm 1.15 b$ & $3.33 \pm 0.58 \mathrm{ab}$ \\
\hline LS2 & $83.00 \pm 2.65 a$ & $\begin{array}{l}47.00 \pm \\
2.00 \mathrm{abc}\end{array}$ & $\begin{array}{c}101.00 \pm \\
3.61 \mathrm{a}\end{array}$ & $58.00 \pm 2.00 \mathrm{ab}$ & $2.33 \pm 1.53 b$ & $1.33 \pm 0.58 b$ \\
\hline LS3 & $85.00 \pm 3.00 a$ & $48.00 \pm 2.00 \mathrm{ab}$ & $\begin{array}{c}101.67 \pm \\
3.06 \mathrm{a}\end{array}$ & $57.33 \pm 1.53 a b c$ & $\begin{array}{c}10.00 \pm 0.00 \\
b\end{array}$ & $4.66 \pm 2.52 a b$ \\
\hline LS4 & $87.33 \pm 3.21 a$ & $47.00 \pm 1.00 \mathrm{abc}$ & $\begin{array}{c}101.00 \pm \\
3.61 \mathrm{a}\end{array}$ & $\begin{array}{c}54.33 \pm \\
3.21 \text { abcde }\end{array}$ & $3.66 \pm 1.53 b$ & $8.66 \pm 8.02 a b$ \\
\hline LS5 & $84.33 \pm 3.06 a$ & $\begin{array}{l}41.00 \pm \\
2.00 \mathrm{bcde}\end{array}$ & $99.00 \pm 6.56 a$ & $\begin{array}{c}49.66 \pm \\
1.53 c d e f g\end{array}$ & $2.33 \pm 2.31 b$ & $2.00 \pm 1.00 \mathrm{ab}$ \\
\hline CC & $82.00 \pm 2.65 a$ & $32.00 \pm 1.00 f$ & $\begin{array}{c}102.33 \pm \\
1.53 a\end{array}$ & $40.66 \pm 2.52 \mathrm{~h}$ & $\begin{array}{c}82.33 \pm \\
49.54 a\end{array}$ & $\begin{array}{c}16.00 \pm \\
14.00 \mathrm{a}\end{array}$ \\
\hline LS6 & & $\begin{array}{c}42.00 \pm \\
2.00 \mathrm{abcde}\end{array}$ & & $\begin{array}{c}50.33 \pm \\
2.52 \mathrm{bcdefg}\end{array}$ & & $5.33 \pm 1.53 a b$ \\
\hline LS7 & & $\begin{array}{c}42.00 \pm \\
4.00 \mathrm{abcde}\end{array}$ & & $\begin{array}{c}51.33 \pm \\
4.51 \mathrm{bcdefg}\end{array}$ & & $5.66 \pm 1.53 \mathrm{ab}$ \\
\hline LS8 & & $36.00 \pm 1.00 \mathrm{ef}$ & & $45.00 \pm 1.00 \mathrm{gh}$ & & $3.00 \pm 1.00 \mathrm{ab}$ \\
\hline LS9 & & $37.00 \pm 1.00 \mathrm{ef}$ & & $45.66 \pm 3.06 \mathrm{fgh}$ & & $1.33 \pm 0.58 b$ \\
\hline LS10 & & $\begin{array}{c}43.00 \pm \\
6.00 \mathrm{abcde}\end{array}$ & & $\begin{array}{c}53.33 \pm \\
4.16 \mathrm{abcdef}\end{array}$ & & $5.33 \pm 3.21 \mathrm{ab}$ \\
\hline LS11 & & $35.66 \pm 4.16 \mathrm{ef}$ & & $46.66 \pm 4.04$ efgh & & $8.66 \pm 1.53 \mathrm{ab}$ \\
\hline LS12 & & $\begin{array}{l}40.00 \pm \\
4.00 \mathrm{cde}\end{array}$ & & $\begin{array}{c}51.66 \pm \\
3.21 \mathrm{abcdefg}\end{array}$ & & $\begin{array}{l}10.33 \pm \\
9.29 \mathrm{ab}\end{array}$ \\
\hline LS13 & & $\begin{array}{l}41.00 \pm \\
2.00 \mathrm{bcde}\end{array}$ & & $\begin{array}{c}49.66 \pm \\
2.52 \text { cdefg }\end{array}$ & & $2.00 \pm 1.00 \mathrm{ab}$ \\
\hline LS14 & & $\begin{array}{c}45.00 \pm \\
2.00 \mathrm{abcd}\end{array}$ & & $\begin{array}{c}54.66 \pm \\
4.73 a b c d\end{array}$ & & $6.00 \pm 1.00 \mathrm{ab}$ \\
\hline LS15 & & $38.00 \pm 2.00 \mathrm{def}$ & & $\begin{array}{c}47.66 \pm \\
\text { 3.06defgh }\end{array}$ & & $4.66 \pm 2.08 \mathrm{ab}$ \\
\hline LS16 & & $38.00 \pm 1.00 \mathrm{def}$ & & $\begin{array}{c}47.33 \pm \\
0.58 \text { defgh } \\
\end{array}$ & & $9.66 \pm 2.52 a b$ \\
\hline LS17 & & $48.00 \pm 1.00 \mathrm{ab}$ & & $57.33 \pm 3.51 \mathrm{abc}$ & & $4.66 \pm 8.02 \mathrm{ab}$ \\
\hline AVR $\pm S D$ & $82.61 \pm 4.91$ & $41.64 \pm 5.54$ & $100.28 \pm 4.57$ & $51.11 \pm 5.80$ & $\begin{array}{c}17.16 \pm \\
34.60 \\
\end{array}$ & $5.70 \pm 5.32$ \\
\hline
\end{tabular}

$L S=L$. siceraria $C C=C$. Colocynthis $S D=S$ Standard deviation, There is no significant difference between the means that have the same letters in each column. ${ }^{*}$ Sabo et al., 2014. Accepted for publication

Average comparison of cultivars for the weight and dimensions of berries : According to table 5 , the weight and the length of a berry help distinguish the cultivars in the 1st year. Indeed, two groups were observed for weight and three for length. Citrullus Colocynthis cultivar gave the heaviest berries with $475 \mathrm{~g}$ and the shortest with $9.5 \mathrm{~cm}$. Lighter berries weighed between 88 and $156 \mathrm{~g}$. LS1 and LS5 cultivars gave the highest berries with respectively 40 and $35 \mathrm{~cm}$ of length and guitar form and big ladle. LS3 is intermediate among berries of $21 \mathrm{~cm}$ of length and the other form the same group as $\mathrm{CC}$ with berries of $10 \mathrm{~cm}$ in height. The variance Analysis showed that the difference was not significant between cultivars for the width of berries. The second year we found Citrullus colocynthis berries heavier with $777 \mathrm{~g}$. followed by LS3 and LS4 cultivars with 420 and $223 \mathrm{~g}$ of berry weight respectively. Less heavy cultivars berries weighed between 26 and $54 \mathrm{~g}$. The highest berries measured 
Sabo et al. J. Appl. Biosci. 2014. Agronomic characterization of eighteen cucrbitaceae cultivars used for food in Niger

between $14,24 \mathrm{~cm}$, and the widest $15 \mathrm{~cm}$. CC Berries,

LS4 cultivars were circular with for the two years

respectively and $9.4012 \mathrm{~cm}$ and $10 \mathrm{~cm}$ and $15 \mathrm{~cm}$

Table 5: Comparison of different cultivars averages of weight, width and length of the berries.

\begin{tabular}{|c|c|c|c|c|c|c|}
\hline cultivar & \multicolumn{2}{|c|}{ Weight of a berry $(\mathrm{g})$} & \multicolumn{2}{|c|}{ Width of a berry $(\mathrm{cm})$} & \multicolumn{2}{|c|}{ Length of a berry $(\mathrm{cm})$} \\
\hline & $1^{\text {st }}$ Year & $2^{\text {nd }}$ Year & 1st Year & $2^{\text {nd }}$ Year & $1^{\text {st }}$ Year & $2^{\text {nd }}$ Year \\
\hline LS1 & $149.67 \pm 16.50 \mathrm{~b}$ & $53.33 \pm 34.64 c$ & $7.36 \pm 2.80 \mathrm{a}$ & $8.22 \pm 2.55 \mathrm{~cd}$ & $\begin{array}{c}40.06 \pm \\
0.81 \mathrm{a}\end{array}$ & $\begin{array}{l}21.77 \pm \\
5.98 \mathrm{abc}\end{array}$ \\
\hline LS2 & $66.67 \pm 28.87 b$ & $30.00 \pm 20.00 \mathrm{c}$ & $7.00 \pm 1.00 \mathrm{a}$ & $12.25 \pm 5.58 \mathrm{~cd}$ & $\begin{array}{c}10.66 \pm \\
1.15 c\end{array}$ & $\begin{array}{l}18.29 \pm \\
8.54 a b c\end{array}$ \\
\hline LS3 & $36.33 \pm 84.10 \mathrm{~b}$ & $419.89 \pm 33.36 b$ & $\begin{array}{c}10.03 \pm \\
3.46 \mathrm{a}\end{array}$ & $\begin{array}{l}14.88 \pm \\
4.35 \mathrm{bcd}\end{array}$ & $\begin{array}{c}20.71 \pm \\
2.13 b\end{array}$ & $\begin{array}{l}23.55 \pm \\
6.67 \mathrm{abc}\end{array}$ \\
\hline LS4 & $88.33 \pm 1.53 b$ & $\begin{array}{l}223.00 \pm \\
79.99 \mathrm{bc}\end{array}$ & $9.25 \pm 2.41 \mathrm{a}$ & $\begin{array}{l}14.86 \pm \\
0.21 \mathrm{bcd}\end{array}$ & $\begin{array}{c}10.00 \pm \\
2.50 c\end{array}$ & $\begin{array}{l}14.86 \pm \\
0.21 \mathrm{abc}\end{array}$ \\
\hline LS5 & $156.00 \pm 5.29 \mathrm{~b}$ & $26.67 \pm 11.55 c$ & $8.50 \pm 0.50 a$ & $8.49 \pm 3.68 \mathrm{~cd}$ & $\begin{array}{c}35.33 \pm \\
4.25 a\end{array}$ & $\begin{array}{l}19.24 \pm \\
5.63 \mathrm{abc}\end{array}$ \\
\hline CC & $474.67 \pm 57.77 a$ & $776.33 \pm 25.56 a$ & $9.38 \pm 0.39 a$ & $12.02 \pm 0.70 \mathrm{~cd}$ & $9.39 \pm 0.38 c$ & $12.02 \pm 0.70 c$ \\
\hline LS6 & & $\begin{array}{c}110.78 \pm \\
108.35 c\end{array}$ & & $17.16 \pm 9.69 \mathrm{bc}$ & & $\begin{array}{l}28.19 \pm \\
12.18 \mathrm{ab}\end{array}$ \\
\hline LS7 & & $\begin{array}{l}253.00 \pm \\
41.55 \mathrm{bc}\end{array}$ & & $14.13 \pm 1.58 \mathrm{~cd}$ & & $28.55 \pm 3.10 a$ \\
\hline LS8 & & $\begin{array}{l}150.33 \pm \\
20.50 \mathrm{bc}\end{array}$ & & $13.04 \pm 0.90 \mathrm{~cd}$ & & $12.99 \pm 0.90 \mathrm{bc}$ \\
\hline LS9 & & $67.00 \pm 15.00 c$ & & $8.74 \pm 0.72 \mathrm{~cd}$ & & $11.70 \pm 0.66 c$ \\
\hline LS10 & & $107.33 \pm 99.73 c$ & & $29.33 \pm 4.51 \mathrm{a}$ & & $29.33 \pm 4.5 a$ \\
\hline LS11 & & $30.67 \pm 30.75 c$ & & $7.24 \pm 3.33 \mathrm{~cd}$ & & $\begin{array}{l}18.22 \pm \\
6.05 \mathrm{abc}\end{array}$ \\
\hline LS12 & & $\begin{array}{l}110.00 \pm \\
104.40 \mathrm{c}\end{array}$ & & $10.65 \pm 3.90 \mathrm{~cd}$ & & $\begin{array}{l}16.44 \pm \\
2.50 \mathrm{abc}\end{array}$ \\
\hline LS13 & & $95.33 \pm 55.00 c$ & & $25.11 \pm 2.50 \mathrm{ab}$ & & $\begin{array}{l}25.11 \pm \\
2.50 \mathrm{abc}\end{array}$ \\
\hline LS14 & & $77.33 \pm 83.19 c$ & & $6.33 \pm 0.31 d$ & & $\begin{array}{l}26.89 \pm \\
4.40 \mathrm{abc}\end{array}$ \\
\hline LS15 & & $\begin{array}{l}134.33 \pm \\
99.38 \mathrm{bc}\end{array}$ & & $8.66 \pm 1.76 \mathrm{~cd}$ & & $\begin{array}{l}18.44 \pm \\
6.62 \mathrm{abc}\end{array}$ \\
\hline LS16 & & $1.67 \pm 0.58 \mathrm{c}$ & & $8.99 \pm 0.58 \mathrm{~cd}$ & & $\begin{array}{l}18.77 \pm \\
0.69 \mathrm{abc}\end{array}$ \\
\hline LS17 & & $74.33 \pm 51.73 c$ & & $8.00 \pm 0.35 \mathrm{~cd}$ & & $\begin{array}{l}18.11 \pm \\
1.17 \mathrm{abc}\end{array}$ \\
\hline $\begin{array}{ll}\text { AVG } & \pm \\
\text { SD } & \\
\end{array}$ & $178.61 \pm 145.01$ & $152.30 \pm 200.78$ & $8.58 \pm 1.02$ & $12.67 \pm 1.99$ & $21.02 \pm 1.39$ & $20.11 \pm 2.88$ \\
\hline
\end{tabular}

$L S=L$. siceraria, $C C=C$. Colocynthis, $S D=$ Standard deviation There is no significant difference between the means that have the same letters in each column.

Table 6 demonstrates that, averages comparison highlighted four groups for the number of seeds per berry and three for seeds' weight. In the same way as for the previous characters, Citrullus Colocynthis cultivar distinguished itself with 473 seeds per berry. Less productive in seeds were LS4 and LS5 with 107 and 104 seeds. The heaviest seeds were obtained in LS3 cultivar with $47 \mathrm{~g}$ and the less heavy were obtained with LS5, LS2 and LS4 for fluctuating values between 11 and $16 \mathrm{~g}$. An important variability has been observed for these two characters in the $2^{\text {nd }}$ year. Indeed, 12 groups were formed for the number of seeds and 8 for their weights. Citrullus Colocynthis cultivar was more productive with 747 seeds. Low production was obtained with LS5 for 43 seeds per 
Sabo et al. J. Appl. Biosci. 2014. Agronomic characterization of eighteen cucrbitaceae cultivars used for food in Niger

berry. The highest weight of seeds per berry was observed in LS4 (61g), followed by LS3 $(55 \mathrm{~g})$. The

lightest seeds were obtained with LS5 $(5 \mathrm{~g})$.

Table 6: Comparison of average for cultivars seeds number and for seeds weight per berry

\begin{tabular}{|c|c|c|c|c|}
\hline cultivar & \multicolumn{2}{|c|}{ Number of seeds/berry * $(g)$} & \multicolumn{2}{|c|}{ Weight of seeds/berry (g) } \\
\hline Year & 1 stYear & $2^{\text {nd }}$ Year & 1 st Year & $2^{\text {nd }}$ Year \\
\hline LS1 & $156.67 \pm 50.64 \mathrm{bc}$ & $161.56 \pm 85.09 \mathrm{cdefg}$ & $26.36 \pm 4.53 a b$ & $16.60 \pm 7.08 \mathrm{~cd}$ \\
\hline LS2 & $123.33 \pm 37.87 \mathrm{bc}$ & $54.22 \pm 33.28 \mathrm{fg}$ & $11.85 \pm 25.83 b$ & $8.89 \pm 1.51 \mathrm{~cd}$ \\
\hline LS3 & $291.00 \pm 61.44 b$ & $282.00 \pm 59.27 c$ & $46.56 \pm 16.85 a$ & $54.65 \pm 28.77 a b$ \\
\hline LS4 & $106.33 \pm 94.24 c$ & $436.67 \pm 24.88 b$ & $11.93 \pm 2.50 \mathrm{~b}$ & $60.85 \pm 3.15 a$ \\
\hline LS5 & $103.33 \pm 25.77 c$ & $43.00 \pm 10.39 g$ & $15.49 \pm 4.27 b$ & $4.37 \pm 0.65 d$ \\
\hline $\mathrm{CC}$ & $472.67 \pm 115.00 \mathrm{a}$ & $746.45 \pm 69.32 a$ & $23.92 \pm 6.01 \mathrm{ab}$ & $30.53 \pm 2.60 \mathrm{abcd}$ \\
\hline LS6 & & $155.11 \pm 16.44 \mathrm{cdefg}$ & & $29.73 \pm 5.28 \mathrm{abcd}$ \\
\hline LS7 & & $241.78 \pm 52.92 \mathrm{cde}$ & & $53.39 \pm 14.61 \mathrm{ab}$ \\
\hline LS8 & & $221.33 \pm 46.80 \mathrm{cde}$ & & $35.32 \pm 11.89 \mathrm{abcd}$ \\
\hline LS9 & & $113.78 \pm 4.29 \mathrm{efg}$ & & $16.42 \pm 0.44 \mathrm{~cd}$ \\
\hline LS10 & & $66.33 \pm 19.47 \mathrm{fg}$ & & $17.60 \pm 5.02 \mathrm{~cd}$ \\
\hline LS11 & & $129.89 \pm 77.73$ defg & & $18.29 \pm 11.76 \mathrm{~cd}$ \\
\hline LS12 & & $147.78 \pm 37.68 \mathrm{cdefg}$ & & $24.06 \pm 8.44 \mathrm{bcd}$ \\
\hline LS13 & & $121.11 \pm 24.54$ defg & & $17.28 \pm 1.65 \mathrm{~cd}$ \\
\hline LS14 & & $172.56 \pm 45.04 \mathrm{cdefg}$ & & $27.39 \pm 11.63 \mathrm{bcd}$ \\
\hline LS15 & & $262.89 \pm 130.81 \mathrm{~cd}$ & & $39.80 \pm 23.91 \mathrm{abc}$ \\
\hline LS16 & & $196.56 \pm 22.34 \mathrm{cdef}$ & & $31.52 \pm 6.00 \mathrm{abcd}$ \\
\hline LS17 & & $136.44 \pm 30.39$ defg & & $19.15 \pm 4.45 \mathrm{~cd}$ \\
\hline $\mathrm{AVG} \pm \mathrm{SD}$ & $208.89 \pm 150.52$ & $204.97 \pm 166.96$ & $22.68 \pm 14.47$ & $28.10 \pm 18.06$ \\
\hline
\end{tabular}

$L S=L$. siceraria, $C C=C$. Colocynthis, $S D=$ Standard deviation There is no significant difference between the means that have the same letters in each column. * Sabo et al., 2014. Accepted for publication

Average Comparison test of cultivars for seeds parameters : Table 7 shows that two groups were observed for each of the characters. In the first year, the highest seeds measured between 1 to $1.5 \mathrm{~cm}$ and the less high $0.55 \mathrm{~cm}$. In the second year, the highest seeds were obtained in LS2 for $4.23 \mathrm{~cm}$ and the less high 0.86 $\mathrm{cm}$. As for the width, 4 groups were formed the first year and two the $2^{\text {nd }}$ year. The LS2 cultivar distinguished itself with $4.34 \mathrm{~cm}$, year 2 . We also note that CC seeds were the smallest on the two years with $0.31 \mathrm{~cm}$ year 1 and
$0.52 \mathrm{~cm}$ year 2. The width length ratio that provides information on seeds form highlighted lying seeds (ratio less than 1) for all cultivars except LS2 cultivar the $2^{\text {nd }}$ year which produced large seeds (ration higher than 1 ).No difference has been observed between cultivars for the variable weight of a seed year 1 . In the $2^{\text {nd }}$ year, two groups were identified with LS2 coming in first position with $3 \mathrm{~g}$. The lightest seeds were observed in CC with 0 . $04 \mathrm{~g}$. 
Table 7: Comparison of different cultivars averages for the length, the width, the width length ratio and weight of a seed.

\begin{tabular}{|c|c|c|c|c|c|c|c|c|c|}
\hline Cultivar & Length of a & ed $(\mathrm{cm})$ & Width of a & $\operatorname{eed}(\mathrm{cm})$ & Width/len & & & Weight of & $\operatorname{seed}(g)$ \\
\hline Year & $1^{\text {st }}$ Year & $2^{\text {nd }}$ Year & $1^{\text {st }}$ Year & $2^{\text {nd }}$ Year & $1^{\text {st }}$ Year & $2^{\text {nd }} Y e a$ & & $1^{\text {st }}$ Year & $2^{\text {nd }}$ Year \\
\hline LS1 & $1.28 \pm 0.10 a$ & $\begin{array}{ll}1.15 & \pm \\
0.04 b & \end{array}$ & $\begin{array}{ll}0.57 & \pm \\
0.05 a b & \end{array}$ & $\begin{array}{ll}0.60 & \pm \\
0.00 \mathrm{~b} & \end{array}$ & $\begin{array}{ll}0.45 & \mathbf{I} \\
0.07 & \end{array}$ & $\begin{array}{l}0.52 \\
0.08\end{array}$ & & $\begin{array}{ll}1.29 & \pm \\
1.89 a & \end{array}$ & $\begin{array}{ll}0.12 & \pm \\
0.01 b & \end{array}$ \\
\hline LS2 & $1.06 \pm 0.06 a$ & $\begin{array}{ll}4.23 & \pm \\
2.80 \mathrm{a} & \end{array}$ & $\begin{array}{ll}0.58 & \pm \\
0.03 \mathrm{ab} & \end{array}$ & $\begin{array}{ll}4.34 & \pm \\
3.66 \mathrm{a} & \end{array}$ & $\begin{array}{ll}0.55 & \mathbf{I} \\
0.15 & \end{array}$ & $\begin{array}{l}1.03 \\
0.01\end{array}$ & \pm & $\begin{array}{l}0.09 \\
0.03 a\end{array}$ & $\begin{array}{l}2.93 \\
2.82 \mathrm{a}\end{array}$ \\
\hline LS3 & $1.15 \pm 64.57 a$ & $\begin{array}{l}1.49 \pm 0.34 \\
b\end{array}$ & $\begin{array}{ll}0.65 & \pm \\
0.05 a & \end{array}$ & $\begin{array}{l}0.63 \\
0.09 b\end{array}$ & $\begin{array}{ll}0.57 & \mathbf{I} \\
0.11 & \end{array}$ & $\begin{array}{l}0.43 \\
0.02\end{array}$ & \pm & $\begin{array}{ll}3.41 & \pm \\
5.70 \mathrm{a} & \end{array}$ & $\begin{array}{l}0.20 \\
0.10 \mathrm{~b}\end{array}$ \\
\hline LS4 & $1.05 \pm 0.13 a$ & $\begin{array}{ll}1.77 & \pm \\
0.07 b & \end{array}$ & $\begin{array}{ll}0.51 & \pm \\
0.06 b & \end{array}$ & $\begin{array}{l}0.72 \\
0.04 b\end{array}$ & $\begin{array}{ll}0.49 & \mathbf{I} \\
0.02 & \end{array}$ & $\begin{array}{l}0.41 \\
0.00\end{array}$ & \pm & $\begin{array}{ll}0.13 & \pm \\
0.02 a & \end{array}$ & $\begin{array}{l}0.13 \\
0.03 b\end{array}$ \\
\hline LS5 & $1.33 \pm 0.12 a$ & $\begin{array}{l}1.68 \\
\pm 0.10 \mathrm{~b}\end{array}$ & $\begin{array}{ll}0.50 & \pm \\
0.00 b & \end{array}$ & $\begin{array}{l}0.65 \\
0.04 b\end{array}$ & $\begin{array}{rl}038 & \mathbf{I} \\
0.02 & \end{array}$ & $\begin{array}{l}0.39 \\
0.41\end{array}$ & \pm & $\begin{array}{ll}0.14 & \pm \\
0.04 a & \end{array}$ & $\begin{array}{l}0.30 \\
0.13 b\end{array}$ \\
\hline CC & $0.55 \pm 0.03 b$ & $\begin{array}{l}0.86 \\
0.06 \mathrm{~b}\end{array}$ & $\begin{array}{ll}0.31 & \pm \\
0.03 c & \end{array}$ & $\begin{array}{ll}0.52 & \pm \\
0.01 b & \end{array}$ & $\begin{array}{ll}0.56 & \mathbf{I} \\
0.00 & \end{array}$ & $\begin{array}{l}0.61 \\
0.00\end{array}$ & \pm & $\begin{array}{ll}0.06 & \pm \\
0.01 \mathrm{a} & \end{array}$ & $\begin{array}{l}0.04 \\
0.00 \mathrm{~b}\end{array}$ \\
\hline LS6 & & $\begin{array}{l}1.54 \\
0.07 \mathrm{~b}\end{array}$ & & $\begin{array}{l}0.50 \\
0.07 b\end{array}$ & & $\begin{array}{l}0.32 \\
0.20\end{array}$ & \pm & & $\begin{array}{l}0.17 \\
0.02 \mathrm{~b}\end{array}$ \\
\hline LS7 & & $\begin{array}{l}1.62 \\
0.27 \mathrm{~b}\end{array}$ & & $\begin{array}{ll}0.65 & \pm \\
0.05 b & \end{array}$ & & $\begin{array}{l}0.40 \\
0.02\end{array}$ & & & $\begin{array}{l}0.22 \\
0.03 b\end{array}$ \\
\hline LS8 & & $\begin{array}{l}1.71 \\
0.03 b \\
\end{array}$ & & $\begin{array}{ll}0.71 & \pm \\
0.03 b & \\
\end{array}$ & & $\begin{array}{l}0.42 \\
0.00\end{array}$ & & & $\begin{array}{l}0.17 \\
0.01 b\end{array}$ \\
\hline LS9 & & $\begin{array}{ll}1.68 & \pm \\
0.05 b & \\
\end{array}$ & & $\begin{array}{ll}0.67 & \pm \\
0.01 b & \end{array}$ & & $\begin{array}{l}0.40 \\
0.01\end{array}$ & & & $\begin{array}{l}0.14 \\
0.01 \mathrm{~b}\end{array}$ \\
\hline LS10 & & $\begin{array}{ll}1.54 & \pm \\
0.17 b & \\
\end{array}$ & & $\begin{array}{ll}0.55 & \pm \\
0.05 b & \\
\end{array}$ & & $\begin{array}{l}0.36 \\
0.00\end{array}$ & & & $\begin{array}{l}0.30 \\
0.08 b\end{array}$ \\
\hline LS11 & & $\begin{array}{ll}1.23 & \pm \\
0.04 b & \end{array}$ & & $\begin{array}{ll}0.70 & \pm \\
0.03 b & \end{array}$ & & $\begin{array}{l}0.57 \\
0.07\end{array}$ & & & $\begin{array}{ll}0.13 & \pm \\
0.04 b & \end{array}$ \\
\hline LS12 & & $\begin{array}{ll}1.43 & \pm \\
0.17 b & \end{array}$ & & $\begin{array}{ll}0.67 & \pm \\
0.13 b & \end{array}$ & & $\begin{array}{l}0.47 \\
0.34\end{array}$ & & & $\begin{array}{ll}0.18 & \pm \\
0.08 b & \end{array}$ \\
\hline LS13 & & $\begin{array}{ll}1.58 & \pm \\
0.13 b & \end{array}$ & & $\begin{array}{ll}0.62 & \pm \\
0.09 b & \end{array}$ & & $\begin{array}{l}0.39 \\
0.00\end{array}$ & \pm & & $\begin{array}{ll}0.23 & \pm \\
0.03 b & \end{array}$ \\
\hline LS14 & & $\begin{array}{ll}1.27 & \pm \\
0.07 b & \end{array}$ & & $\begin{array}{ll}0.79 & \pm \\
0.03 b & \end{array}$ & & $\begin{array}{l}0.62 \\
0.05\end{array}$ & \pm & & $\begin{array}{ll}0.15 & \pm \\
0.03 b & \end{array}$ \\
\hline LS15 & & $\begin{array}{ll}1.32 & \pm \\
0.05 b & \end{array}$ & & $\begin{array}{ll}0.84 & \pm \\
0.02 \mathrm{~b} & \end{array}$ & & $\begin{array}{l}0.64 \\
0.10\end{array}$ & & & $\begin{array}{ll}0.14 & \pm \\
0.03 b & \end{array}$ \\
\hline LS16 & & $\begin{array}{ll}1.36 & \pm \\
0.07 b & \end{array}$ & & $\begin{array}{ll}0.83 & \pm \\
0.09 \mathrm{~b} & \end{array}$ & & $\begin{array}{l}0.61 \\
0.01\end{array}$ & & & $\begin{array}{ll}0.15 & \pm \\
0.02 b & \end{array}$ \\
\hline LS17 & & $\begin{array}{ll}1.19 & \pm \\
0.07 b & \end{array}$ & & $\begin{array}{ll}0.72 & \pm \\
0.05 b & \end{array}$ & & $\begin{array}{l}0.61 \\
0.01\end{array}$ & & & $\begin{array}{ll}0.16 & \pm \\
0.01 b & \end{array}$ \\
\hline $\begin{array}{l}\text { AVG } \pm \\
\text { SD }\end{array}$ & $1.07 \pm 0.27$ & $1.59 \pm 0.88$ & $\begin{array}{l}0.52 \\
0.11\end{array}$ & $0.87 \pm 1.11$ & $\begin{array}{ll}0.50 & \pm \\
0.08 & \end{array}$ & $\begin{array}{l}0.51 \\
0.16\end{array}$ & & $\begin{array}{ll}0.85 & \pm \\
2.41 & \end{array}$ & $\begin{array}{l}0.32 \\
0.84\end{array}$ \\
\hline
\end{tabular}

$L S=L$. siceraria, $C C=C$. Colocynthis, $S D=$ Standard deviation There is no significant difference between the means that have the same letters in each column.

Results of the correlation analysis between the studied characters: It comes out from table 8 that there were positive and negative correlations between different variables. Year 1 , cultivars which rose lately produced many berries $(r=0.6151)$ with a weight corresponding to $(r=0.6832)$ and having an important number of seeds per berry $(r=0.6303)$. Berries obtained were less large $(r=-$ $0.6223)$ and less long $(r=-0.4929)$. In cultivars which 

food in Niger

flowered and fructified late, we observed fewer berries $(r$ $=-0.5200$ for the flowering and $r=-0.4409$ for the fructification). Those which produced many berries, give heavy berries $(r=0.7654)$, more seeds $(r=0.6121)$ of small heights $(r=-0.6619$ for width and -0.7288 for length). An important number of seeds was produced by the heavy $(r=0.8240)$ and large $(r=0.4717)$. The big berries were also very large $(r=0.5564)$ and provide many seeds $(r=0.5425)$ and we noted a positive correlation between the length of a berry and that of the seed $(r=0.6797)$. In table 9, cultivars which germinated late, fructified late $(r=0.4500)$. The high rate of emergence recorded gave less long seeds $(r=-0.4214)$, less large $(r=-0.4126)$ and of low weight $(r=-0.4711)$. The big berries were obtained with productive cultivars $(r$ $=0.4051)$, and they were the ones which provided many seeds $(r=0.5008)$. Berries of large dimensions gave the heaviest seeds $(r=0.9911$ for length and 0.5313 for width). The heaviest seeds were also the longest $(r=$ 0.9639). These later ones were also the largest $(r=$ 0.9557).

Table 8: Correlation Matrix (Pearson) between the different characters in year one.

\begin{tabular}{|c|c|c|c|c|c|c|c|c|c|c|c|c|}
\hline & $\mathrm{DE}$ & ER & FLO & FRU & NBP & WtB & LB & WB & NSB & WtSB & WtS & LS \\
\hline $\begin{array}{l}\text { ERP- } \\
\text { value }\end{array}$ & $\begin{array}{l}- \\
0.0926 \\
0.7146\end{array}$ & & & & & & & & & & & \\
\hline FLO & $\begin{array}{l}- \\
0.3711 \\
0.1295\end{array}$ & $\begin{array}{l}0.1499 \\
0.5528\end{array}$ & & & & & & & & & & \\
\hline FRU & $\begin{array}{l}0.0502 \\
0.8431\end{array}$ & $\begin{array}{l}0.2802 \\
0.2601\end{array}$ & $\begin{array}{l}0.2433 \\
0,3306\end{array}$ & & & & & & & & & \\
\hline NBP & $\begin{array}{l}0.0323 \\
0.2228\end{array}$ & $\begin{array}{l}0.6151 \\
0.0066\end{array}$ & $\begin{array}{l}0.0575 \\
0.8207\end{array}$ & $\begin{array}{l}0.2368 \\
0.3440\end{array}$ & & & & & & & & \\
\hline WtB & $\begin{array}{l}0.3613 \\
0.1406\end{array}$ & $\begin{array}{l}0.6832 \\
0.0018\end{array}$ & $\begin{array}{l}- \\
0.1839 \\
0.4650\end{array}$ & $\begin{array}{l}0.1687 \\
0.5034\end{array}$ & $\begin{array}{l}0.7654 \\
0.0002\end{array}$ & & & & & & & \\
\hline LB & $\begin{array}{l}0.1653 \\
0.5121\end{array}$ & $\begin{array}{l}- \\
0.4929 \\
0.0377\end{array}$ & $\begin{array}{l} \\
0.5200 \\
0.0270\end{array}$ & $\begin{array}{l} \\
0.4409 \\
0.0671\end{array}$ & $\begin{array}{l}- \\
0.3780 \\
0.1219\end{array}$ & $\begin{array}{l}- \\
0.1876 \\
0.4561\end{array}$ & & & & & & \\
\hline W B & $\begin{array}{l}0.0594 \\
0.8150\end{array}$ & $\begin{array}{l}0.1018 \\
0.6876\end{array}$ & $\begin{array}{l}0.0981 \\
0.6986\end{array}$ & $\begin{array}{l}0.3721 \\
0.1284\end{array}$ & $\begin{array}{l}0.1417 \\
0.5749\end{array}$ & $\begin{array}{l}0.3050 \\
0.2184\end{array}$ & $\begin{array}{l}- \\
0.1060 \\
0.6755\end{array}$ & & & & & \\
\hline NSB & $\begin{array}{l}0.2671 \\
0.2839\end{array}$ & $\begin{array}{l}0.6303 \\
0.0050\end{array}$ & $\begin{array}{l} \\
0.1084 \\
0.6685\end{array}$ & $\begin{array}{l}0.1779 \\
0.4799\end{array}$ & $\begin{array}{l}0.6121 \\
0.0069\end{array}$ & $\begin{array}{l}0.8240 \\
0.0000\end{array}$ & $\begin{array}{l} \\
0.3014 \\
0.2241\end{array}$ & $\begin{array}{l}0.4717 \\
0.0481\end{array}$ & & & & \\
\hline WtSB & $\begin{array}{l}0.1063 \\
0.6748\end{array}$ & $\begin{array}{l}0.0488 \\
0.8474\end{array}$ & $\begin{array}{l}- \\
0.1638 \\
0.5160\end{array}$ & $\begin{array}{l}0.0394 \\
0.8767\end{array}$ & $\begin{array}{l}0.0312 \\
0.9020\end{array}$ & $\begin{array}{l}0.2310 \\
0.3563\end{array}$ & $\begin{array}{l}0.2087 \\
0.4060\end{array}$ & $\begin{array}{l}0.5564 \\
0.0165\end{array}$ & $\begin{array}{l}0.5425 \\
0.0200\end{array}$ & & & \\
\hline WtS & $\begin{array}{l}0.0081 \\
0.9745\end{array}$ & $\begin{array}{l}- \\
0.0536 \\
0.8329\end{array}$ & $\begin{array}{l}0.1441 \\
0.5684\end{array}$ & $\begin{array}{l}0.1662 \\
0.5097\end{array}$ & $\begin{array}{l}0.0925 \\
0.7149\end{array}$ & $\begin{array}{l}0.0569 \\
0.8224\end{array}$ & $\begin{array}{l}0.1666 \\
0.5088\end{array}$ & $\begin{array}{l}0.4795 \\
0.0440\end{array}$ & $\begin{array}{l}0.1529 \\
0.5446\end{array}$ & $\begin{array}{l}0.7275 \\
0.0006\end{array}$ & & \\
\hline LS & $\begin{array}{l}- \\
0.2028 \\
0.4195\end{array}$ & $\begin{array}{l}0.6044 \\
0.0079\end{array}$ & $\begin{array}{l} \\
0.1546 \\
0.5402\end{array}$ & $\begin{array}{l} \\
0.3057 \\
0.2173\end{array}$ & $\begin{array}{l} \\
0.7288 \\
0.0006\end{array}$ & $\begin{array}{l} \\
0.6955 \\
0.0014\end{array}$ & $\begin{array}{l}0.6797 \\
0.0019\end{array}$ & $\begin{array}{l} \\
0.2139 \\
0,3941\end{array}$ & $\begin{array}{l} \\
0.7338 \\
0.0005\end{array}$ & $\begin{array}{l}0.0616 \\
0.8081\end{array}$ & $\begin{array}{l}0.3012 \\
0.2245\end{array}$ & \\
\hline WS & $\begin{array}{l}- \\
0.1453 \\
0.5650\end{array}$ & $\begin{array}{l}0.6223 \\
0.0058\end{array}$ & $\begin{array}{l}0.0282 \\
0.9116\end{array}$ & $\begin{array}{l}- \\
0.1424 \\
0.5730\end{array}$ & $\begin{array}{l}0.6619 \\
0.0028\end{array}$ & $\begin{array}{l}0.7870 \\
0.0001\end{array}$ & $\begin{array}{l}0.2911 \\
0.2412\end{array}$ & $\begin{array}{l}- \\
0.1740 \\
0.4900\end{array}$ & $\begin{array}{l} \\
0.5575 \\
0.0162\end{array}$ & $\begin{array}{l}0.2695 \\
0.2794\end{array}$ & $\begin{array}{l}0.3587 \\
0.1438\end{array}$ & $\begin{array}{l}0.7332 \\
0.0005\end{array}$ \\
\hline
\end{tabular}

DE: date of emergence; ER: emergence rate; FLO: flowering FRU: fructification; NBP: number of berries per plant. WtB: weight of berry. LB: length of berry; WB: width of Berry; NSB: number of seeds per berry; WtSB: weight of seeds per berry. WtS: weight of a seed. LS: length of a seed; WS: width of a seed. Bold $=p<5 \%<$ 
Table 9: Matrix Correlation (Pearson) between different characters in year 2.

\begin{tabular}{|c|c|c|c|c|c|c|c|c|c|c|c|c|}
\hline & $\mathrm{DE}$ & ER & FLO & FRU & NBP & WtB & LB & WB & NSB & WtSB & WtS & LS \\
\hline $\begin{array}{l}\text { ERP- } \\
\text { value }\end{array}$ & $\begin{array}{l}0.0567 \\
0.6839\end{array}$ & & & & & & & & & & & \\
\hline FLO & $\begin{array}{l}0.4552 \\
0.0005\end{array}$ & $\begin{array}{l}- \\
0.1191 \\
0.3908\end{array}$ & & & & & & & & & & \\
\hline FRU & $\begin{array}{l}0.4500 \\
0.0006\end{array}$ & $\begin{array}{l}- \\
0.1383 \\
0.3187\end{array}$ & $\begin{array}{l}0.9608 \\
0.0000\end{array}$ & & & & & & & & & \\
\hline NBP & $\begin{array}{l}- \\
0.2967 \\
0.0293\end{array}$ & $\begin{array}{l}0.2102 \\
0.1271\end{array}$ & $\begin{array}{l}- \\
0.2470 \\
0.0718\end{array}$ & $\begin{array}{l}- \\
0.2527 \\
0.0653\end{array}$ & & & & & & & & \\
\hline WtB & $\begin{array}{l}- \\
0.3434 \\
0.0110\end{array}$ & $\begin{array}{l}0.1789 \\
0.1954\end{array}$ & $\begin{array}{l}0.2752 \\
0.0440\end{array}$ & $\begin{array}{l}- \\
0.3136 \\
0.0209\end{array}$ & $\begin{array}{l}0.4051 \\
0.0024\end{array}$ & & & & & & & \\
\hline LS & $\begin{array}{l}0.0737 \\
0.5963\end{array}$ & $\begin{array}{l}- \\
0.0711 \\
0.6092\end{array}$ & $\begin{array}{l}0.2545 \\
0.0633\end{array}$ & $\begin{array}{l}0.2247 \\
0.1023\end{array}$ & $\begin{array}{l}- \\
0.1365 \\
0.3250\end{array}$ & $\begin{array}{l}- \\
0.0421 \\
0.7627\end{array}$ & & & & & & \\
\hline W S & $\begin{array}{l}- \\
0.0249 \\
0.8583\end{array}$ & $\begin{array}{l}- \\
0.1407 \\
0.3102\end{array}$ & $\begin{array}{l}0.0525 \\
0.7061\end{array}$ & $\begin{array}{l}0.0213 \\
0.8784\end{array}$ & $\begin{array}{l}- \\
0.1192 \\
0.3905\end{array}$ & $\begin{array}{l}0.1586 \\
0.2520\end{array}$ & $\begin{array}{l}0.5313 \\
0.0000\end{array}$ & & & & & \\
\hline NSB & $\begin{array}{l}- \\
0.3834 \\
0.0042\end{array}$ & $\begin{array}{l}0.2788 \\
0.0412\end{array}$ & $\begin{array}{l}\overline{-} \\
0.3132 \\
0.0211\end{array}$ & $\begin{array}{l} \\
0.3750 \\
0.0052\end{array}$ & $\begin{array}{l}0.5008 \\
0.0001\end{array}$ & $\begin{array}{l}0.8458 \\
0.0000\end{array}$ & $\begin{array}{l}- \\
0.2016 \\
0.1437\end{array}$ & $\begin{array}{l}- \\
0.0120 \\
0.9315\end{array}$ & & & & \\
\hline WtSB & $\begin{array}{l}0.3364 \\
0.0129\end{array}$ & $\begin{array}{l}0.2701 \\
0.0482\end{array}$ & $\begin{array}{l}0.0016 \\
0.9909\end{array}$ & $\begin{array}{l}- \\
0.0745 \\
0.5924\end{array}$ & $\begin{array}{l}0.2255 \\
0.1010\end{array}$ & $\begin{array}{l}0.4880 \\
0.0002\end{array}$ & $\begin{array}{l}0.2047 \\
0.1377\end{array}$ & $\begin{array}{l}0.1328 \\
0.3382\end{array}$ & $\begin{array}{l}0.5766 \\
0.0000\end{array}$ & & & \\
\hline WtS & $\begin{array}{l}0.1333 \\
0.3365\end{array}$ & $\begin{array}{l}- \\
0.4111 \\
0.0020\end{array}$ & $\begin{array}{l}0.2132 \\
0.1216\end{array}$ & $\begin{array}{l}0.2739 \\
0.0451\end{array}$ & $\begin{array}{l}- \\
0.1625 \\
0.2403\end{array}$ & $\begin{array}{l}- \\
0.1429 \\
0.2797\end{array}$ & $\begin{array}{l}- \\
0.1570 \\
0.2569\end{array}$ & $\begin{array}{l}- \\
0.0839 \\
0.5462\end{array}$ & $\begin{array}{l}- \\
0.2354 \\
0.0866\end{array}$ & $\begin{array}{l}- \\
0.2103 \\
0.1270\end{array}$ & & \\
\hline LS & $\begin{array}{l}0.1245 \\
0.3698\end{array}$ & $\begin{array}{l}- \\
0.4214 \\
0.0015\end{array}$ & $\begin{array}{l}0.2178 \\
0.1137\end{array}$ & $\begin{array}{l}0.2553 \\
0.0624\end{array}$ & $\begin{array}{l}- \\
0.2417 \\
0.0783\end{array}$ & $\begin{array}{l}- \\
0.1980 \\
0.1512\end{array}$ & $\begin{array}{l} \\
0.1523 \\
0.2715\end{array}$ & $\begin{array}{l}- \\
0.0156 \\
0.9109\end{array}$ & $\begin{array}{l}- \\
0.2799 \\
0.0403\end{array}$ & $\begin{array}{l} \\
0.1210 \\
0.3833\end{array}$ & $\begin{array}{l}0.9639 \\
0.0000\end{array}$ & \\
\hline WS & $\begin{array}{l}0.0951 \\
0.4940\end{array}$ & $\begin{array}{l}- \\
0.4126 \\
0.0019\end{array}$ & $\begin{array}{l}0.1994 \\
0.1482\end{array}$ & $\begin{array}{l}0.2624 \\
0.0552\end{array}$ & $\begin{array}{l}- \\
0,1401 \\
0.3124\end{array}$ & $\begin{array}{l}- \\
0.1566 \\
0.2583\end{array}$ & $\begin{array}{l}- \\
0.2190 \\
0.1116\end{array}$ & $\begin{array}{l}- \\
0.1594 \\
0.2497\end{array}$ & $\begin{array}{l}- \\
0.2030 \\
0.1409\end{array}$ & $\begin{array}{l}- \\
0.1884 \\
0.1724\end{array}$ & $\begin{array}{l}0.9911 \\
0.0000\end{array}$ & $\begin{array}{l}0.9557 \\
0.0000\end{array}$ \\
\hline
\end{tabular}

DL: date of emergence; $R L$ : emergence rate; FLO: flowering FRU: fructification; NBP: number of berries per plant. WtB: weight of berry. LB: length of berry; WB: width of Berry; NSB: number of seeds per berry; WtSP: weight of seeds per berry. WtS: weight of a seed. LS: length of a seed; WS: width of a seed. Bold $=p<5 \%$.

\section{DISCUSSION}

The results showed a great variability of germinating characteristics. Several parameters (species and seeds age) can influence the duration and rate of emergence. Indeed, according to (Dje et al.,2006) in c. melo the rate 

food in Niger

of germination is $5 \%$ for seeds of 18 months age and $32 \%$ for the seeds of 3 months age. The emergence time is 6 and 8 days for the seeds of 18 months age and 5 to 14 days for seeds of 3 months. This shows better rate obtained in the $2^{\text {nd }}$ year, because the seeds were of the previous harvest. According to (Achigan, 2002), the duration of germination of the three studied species (Lagenaria sicerari, C. lanatus, $C$ edulis) varies between 5 and 10 days. The same interval has been obtained by (Zoro et al., 2003) a germination rate, which varies from 85 to $96 \%$ in Lagenaria siceraria. These values were close to those, which we obtained in the $2^{\text {nd }}$ year in this species (50-100\%). According to (Walters et al., 2005), germinating power can be kept for a long time in this species. For the flowering, the 1st year, analysis of variance showed that there was no significant difference between cultivars. We note that the cultivars have been late in the first year. Several environmental phenomena could be associated to these variations, especially in the 1 st year, where we noted drought periods in rainy season. In Dje et al., 2006, the first buds flowers appeared between 39 and 43 (DAS) in the dry season and between 70 and 78 DAS in the rainy season in $\mathrm{C}$. melo. According to (Zoro et al., 2003), this duration varies significantly from one species to another, in c. lanatus from 35 to 38 days and in the Lagenaria siceraria cultivars from 40 to 52 days. This difference between Lagenaria cultivars has been already observed by (Achigan, 2002) who has indicated that the date of flowering is a discriminating character of Lagenaria siceraria populations. In terms of sex determination, we noted that there is a difference in sex appearance, the female flowers appear 8 to 10 days after male flowers. In the two species, female flowers close 24 hours after their opening up and development of the berry, which lasts about three weeks, starts immediately. This difference in sex has already been observed by (Dje et al., 2006), the appearance of males flowers proceeding from 7 to 10 days that of hermaphrodite flowers. The flowering is spaced out so that bud flowers appear on plants after full maturation of the first berries. According to (Achigan, 2002; Zoro et al., 2003) Lagenaria siceraria and Citrullus sp., are monoic species with an asynchronous flowering, the male flowering appearing first with an interval of seven days maximum, in comparison with the female flowering. In terms of fructification, it came out from our study that the cultivars, which have been early or late for flowering, did the same for fructification. At maturity, we observed a yellowing of peduncles of berries and a drying of peduncles three months after the beginning of fructification in Citrullus colocynthis and Lagenaria siceraria. Thus, the duration of fruits maturity cycle varies between 100 and 190 days. This is a very long period, which coincides with the liberation of fields for livestock. (Zhang \& Jiang, 1990) found 120 days in four cultivars of Chinese Cucurbitaceae. (Dje et al., 2006) reported that this period is from 130 to 150 days during the rainy season and 110 to 120 days during the dry season. Indeed, in the dry season, the plant dries out completely while in the rainy season, the production of flowers and berries is much more ranged. At harvest, we recorded a variability of the production in berries from one cultivar to another in Lagenaria siceraria. Citrullus colocynthis has been more productive than Lagenaria siceraria. This production has dropped in the $2^{\text {nd }}$ year. This could be due to the abundant rainfall. However, Citrullus colocynthis is a cultivar which cultivation does not require much water. (Achigan, 2002) indicated that cultivars of Citrullus produce three to four berries per plant; those of Lagenaria produce one to three berries per plant. According to (Dje et al., 2006), the very low production in berries could be resulted from a fertilization problem related to a small number of pollen seeds deposited on the stigma. However, attacks of flowers and fruits by cucurbitaceas ladybirds have been observed. Indeed, pollen seeds (16487 \pm 231 per plant) were released a night before the opening of the flowers as it has been observed in c. pepo by (Nepi \& Paccini, 1993). The amount of viable pollen seeds decreased rapidly during the 24 hours, after the opening of the flower. That is why the female flowers must be pollinated immediately after the opening; otherwise, the pollens will remain relatively viable (Vidal et al., 2006). It has been noted that the flowering date negatively influences the width of the berry and positively the number of seeds per berry. The duration of the emergence has a negative effect on the number of berry, the weight of a berry, the number of seeds per berry, the weight of seeds per berry. The number of berries per plant is positively correlated with the weight of a berry and the number of seed / berry. This strong positive correlation has been also observed in watermelon (Nerson, 2002). Therefore, the weight of Lagenaria siceraria berries could be used as a good criterion to select individuals with a greater number of seeds. This result is harmonious with the findings of (Achigan, 2002). During this study, the heaviest berries were harvested in Citrullus colocynthis, first, followed by LS1, LS3 and LS4. The significant weight of CC berries could be due to the fact that, even at maturity they were fresh, while $L$. siceraria berries were completely dehydrated and form hard shells. Concerning the length in Lagenaria siceraria the longest berries were observed in the second year in 

food in Niger

LS1 and LS5.This concern guitar cultivar (LS1) and the large ladle (LS5).

As for the production of seeds, the most productive cultivars were Citrullus colocynthis, LS3 and LS4. The number of lowest seeds yield has been obtained with LS5 on the two years. This could be related to the form of the berry. Unlike other LS, all of the seeds were concentrated in the bulging base (which gave it its ladle form) whereas for others, the seeds were uniformly distributed throughout the berry. Seeds with high heights were obtained with LS2, LS3 and LS4. The smallest seeds were observed in Citrullus colocynthis with dimensions and weights always ranging in the last group. The seeds obtained were all lying. except those of LS4 which were large. This led to an average production in seeds of 181 $\mathrm{kg} / \mathrm{ha}$ the first year and $705 \mathrm{~kg} / \mathrm{ha}$ in the second year

\section{CONCLUSION}

This study has highlighted on the short and long cycles cultivars, as well as productive and less productive cultivars. Over the two years, all of the characters allow to distinguish different cultivars apart from the duration of the emergence, the date of fruiting, the width of a berry and the weight of a seed, the first year. In Niger, these cultivars are cultivated for the socio-economic interests that provide berries and seeds. The study showed that production in berries and seeds cultivars from one cultivar to another. Unfortunately, there is little research work done on this family. The best yields in berries and seeds are obtained with Citrullus colocynthis followed by the cultivars LS3 and LS4 of Lagenaria siceraria. It has been noted that the low yield in Lagenaria siceraria berries and seeds was composed of large size and heavy berries and seeds comparatively to Citrullus colocynthis that produced seeds with small sizes. Despite the interesting agricultural potentialities of these cultivars, many parameters need to be better detailed, including berries yield, and the cycle of these plants. Mass selection efforts could be a way for performance improvement. Studies should be conducted to have a good command of pollination to improve production, increase the average for the two species. However, it has to be noted that there were very interesting values in Citrullus colocynthis, which is cultivated for its seeds: $500 \mathrm{~kg} / \mathrm{ha}$ in year 1 and $117 \mathrm{~kg} / \mathrm{ha}$ in year 2. (Achigan, 2002) showed that the yield per hectare of the cultivars studied varies from 83 to $600 \mathrm{~kg}^{\text {. ha }}{ }^{-1}$. (Zhang \& Jiang, 1990) noted that the four Chinese cultivars produce $202.5 \mathrm{~kg} / \mathrm{ha}$ in average.

The seeds, on which this study was centred, are of a great importance in many ways for the Niger Republic consumer. Among other important reasons: these plants require less rainfall and inorganic fertilizers to grow. The production of these seeds could help the country achieve food sufficiency, which is in line with the authorities' efforts for a sustainable agriculture based on local plants cultivars.

weight of a berry and reduce their cycles. Indeed, the results gave a low productivity in berries and very long cycles. These long periods coincide with the liberation of fields. It most often leads to conflicts between pastoralists and farmers, which end in the loss of human lives. The production should be encouraged given their high nutritious and monetary values. In addition, a strong correlation was found between the yield in berries (number and weight average of a berry) and the yield in seeds. A better strategy for improvement would be to select individuals producing several large berries per plant. It is in such a way that a gain in seeds is more likely to be obtained. It is therefore important to focus forthcoming varietal improvement programs on seeds productivity. For more information, further studies should be conducted on the floral biology and the degree of sensitivity to parasites of these two species. At the end of this study, the extension of these species may be an important income generating activity and sources of essential nutriments that can help rebalance the nutritional status of the populations in general and children in particular.

\section{ACKNOWLODGMENT}

We are grateful to Abdou Moumouni University of Niamey for its financial support through research funds $N^{\circ} 460$, and International Funds of Sciences (IFS) E/4331-1

\section{REFERENCES}

Abiodun OA and Adeleke RO, 2010, Comparative Studies on Nutritional Composition of Four Melon Seeds Varieties, Pakistan Journal of Nutrition 9 (9): 905-908.
Achigan D, Enoch G, Fanou N, Kouke A, Avohou H, Vodouhe RS, Ahanchede A, 2006. Agronomic evaluation of three Egusi species (Cucurbitaceae) used in food in Benin and 
development of a model for predilection yield. Biotechnology Agronomy Society Environment $10(2)$ : $121-129$.

Achigan DGE, 2002. Morphological characterization and analysis of cucurbitaceae ploïdilevel L. siceraria (Molin.) Standl gender, prospected in Benin and Togo. DEA Memory. UFR Biosciences, Cocody university. Ivory Coast. $52 \mathrm{p}$.

Barilla Center for Food and Nutrition, 2012, Eating planet 2012. Edizioni Ambiente Italy, $315 \mathrm{p}$.

Beshir AA. and Babiker SA. 2009. Digestibility of Sudanese Desert lambs fed Diets of Different Proportions of Watermelon (Citrullus lanatus) Seeds Cake. Research Journal of Animal and Veterinary Sciences, 2009. 4: 30-34.

Dje Y, Leonie C, Kouonon Al, Zoro-BI G, Gnamien Y, Baudoin JP, 2006. Study of the African melon (C. melo L. var agrestis Naudin, Cucurbitaceae.) botanical, agronomic and floral biology characteristics. Biotechnology Agronomy Society Environment 10 (2): 109-119

Gusmini G, 2003.Watermelon (C. lanatus) breeding handbook. Raleigh, NC, USA : North Carolina State University.

Ismail M., Mariod A., Bagalkotkara G. and Lingb HS. 2010. Fatty acids composition and antioxidant activity of oils from two cultivars of Cantaloupe extracted by supercritical fluid extraction. grasas y aceites. 61 (1): 37-44.

Leonie C, Kouonon AL, Jacquemart AL, Arsene I, ZoroBi, Bertin P, Baudoin JP and Dje Y, 2009. Reproductive biology of the andromonoecious Cucumis melo subsp.agrestis. Annals of Botany 104: 1129-1139.

Mohammed BT, 2011. Socio-economic analysis of melon production in Ifelodun Local Government Area, Kwara State, Nigeria, Journal of Development and Agricultural Economics Vol. 3(8) : 362-367,

National Institute of Statistics, 2013 Statistical Yearbook 2010-2013.

Nepi M and Paccini E, 1993. Pollinisation, pollen viability and pistil receptivity in $C$. pepo. Annals of Botany 72 : 527-536.

Nerson H, 2002. Relationships between plant density, berry and seed production in muskmelon. J. Am. Soc. Hortic. Sci 127(5) : 245-256.

Nyam CPT, Lai OM, Long K, Che-Man YB, 2009, Physicochemical properties and bioactive compounds of selected seed oils. Food Science and Technology 42(8) 1396-1403.
Ogundele JO, Oshodi AA, Fakunle CO, Oyebanij, AO and Amoo IA, 2013, Evaluation and comparison of the Amino acid composition of three varieties of Lagerena siceraria melon seed flours, Food Science and Quality Management 15: 36-43.

Peyre BF, 1979. Niger plants Lexicon, IMVT 2nd edition, $144 \mathrm{pp}$.

Sabo H, Sadou H, Amoukou IA, Malam alma M, Mahamane S, 2014, Potentials in vegetable oils and various nutrients of eighteen varieties of Niger Cucurbitaceae, International Journal of Biology and Chemical Sciences.

Schafferman D, Beharav A, Shabelsky E, Yaniv Z. 1998. "Evaluation of Citrullus colocynthis, a desert plant native in Israel, as a potential source of edible oil". Journal of Arid Environments 40: 431-439.

Vidal MDG, Jong DD, Wein HC, Morse RA, 2006, Nectar and pollen production in pumpkin (Cucurbita pepo L.). Revista Brasileira de Botânica 29: 267273.

Walters C, Lana WM, Grotenhuis MJ, 2005. Longevity of seeds stored in a genebank: species characteristics. Seed Sciences Research 15: 120.

Zhang $X$ and Jiang $Y, 1990$. Edible seed watermelons (C. lanatus (thumb.) Matsun et Nakai) in, northwest china. Cucurbit genet. Coop. Rep. 13. P 15-17

Zoro-Bi I, Koffi KK, Dje Y, 2003. Botanic and agronomic characterization of three cucurbitaceae species consumed in sauce in West Africa: Citrullus sp., Cucumeropsis manii, L. siceraria (Molin.) Standl. Biotechnology Agronomy Society Environment 7: 187-199. 